\title{
Paleomagnetism of the Caldwell lavas, Eastern Townships, Québec.
}

\author{
M. K. SEguin * \\ Received on May 20th, 1978
}

\section{Abstract}

Forty two oriented samples (97 specimens) were obtained from 17 sites in metavolcanic rocks from the Caldwell Group of the Appalachians of Southern Québec (longitude: 71000'-71030' W, latitude: 46 $000^{\prime}-46^{\circ} 10^{\prime} \mathrm{N}$ ). These metavolcanics of Lower Cambrian age are massive or pillowed lavas of andesitic and mainly basaltic composition metamorphosed to the sub-greenschist facies. Magnetite and occasionally hematite are the frequent magnetic memory carrier.

In order to obtain some pertinent information relative to the stability of the remanent magnetization component, stepwise alternating field demagnetization was conducted on $35 \%$ of the specimens and the others were demagnetized at an optimum alternating field. After AF treatment, the paleopole position of the tilted formation from 16 lccalities is $148^{\circ} \mathrm{E}$, $43^{\circ} \mathrm{N}\left(\mathrm{dp}=11.3^{\circ}, \mathrm{dm}=22.4^{\circ}\right)$. After omission of 3 localities for which $\alpha 95 \geq 30^{\circ}$, the new paleopole position obtained is $173^{\circ} \mathrm{E}, 26^{\circ} \mathrm{N}$. This formation of Early Cambrian age is characterized by a reversed polarity.

(*) Department de Géologie. Université Laval. Quebec (Canada). 


\section{RI:SUME}

Quarante-deux échantillons orientés (97 spćcimens) ont été obtenus de 17 localités différentes dans des roches métavolcaniques du groupe de Caldwell dans les Appalaches du sud du Québec (longitude: $71{ }^{\circ} 00^{\circ}$. $71^{\circ} 30 \mathrm{~W}$, latitude: $46^{\circ} 00^{\circ}-46^{\circ} 10 \mathrm{~N}$ ). Ces roches comprennent des laves massives et à coussinets de composition andésitique mais surtout basaltique et métamorphosées au faciès des schistes verts. La magnétite et occasionnellement la hématite sont les minćraux porteurs de la mémoire magnétique.

Afin d'obtenir des renseignements pertinents ayant trait à la stabilité de l'aimantation rémanente, on a procédé à un lavage par champ alternatif progressif sur $35 \%$ des spécimens et l'on a désaimanté les autres à une intensité optimum en champ AC. Après lavage magnétique, la position du paléopode de la formation dépliée pour 15 localités est $148^{\circ} \mathrm{E}, 42^{\circ} \mathrm{N}\left(d p=11.3^{\circ}, d m=22.4^{\circ}\right)$. Après avoir omis 3 localités pour les. quelles $\alpha 95>30^{\circ}$, la nouvelle position du paléopole devient $172^{\circ} \mathrm{E}, 26^{\circ} \mathrm{N}$. Cette formation géologique d'âge Cambriùn inférieur est caractérisée par un renversement de polarité.

\section{RIASSUNTO}

Sono stati ottenuti quarantadue campioni orientati (97 esemplari) da 17 località differenti nelle rocce metavulcaniche del gruppe del Caldwell, negli Appalachiani del sud Quebec (long.: $71^{\circ} \mathrm{C} 0^{\prime}-71^{\circ} 30^{\prime} \mathrm{W}$, lat.: $46^{\circ} 00^{\prime}$ '. $46^{\circ} 10^{\prime} \mathrm{N}$ ). Tali rocce comprendono lave massive ed a cuscinetti di composizione per lo piu basaltica ed andesilica e metamorfizzate in facies di scisti verdi.

La magnetite e, occasionalmente, l'ematite sono i minerali condut. tori della memoria magnetica.

Al fine di ottenere indicazioni pertinenti attinte dalla stabilità della magnetizzazione residua, si è proceduto ad un lavaggio per campo alternato progressivo sul 35\% degli esemplari, demagnetizzando gli altri ad un'intensità ottimale in campo AC. Dopo il lavaggio magnetico, la posizione del paleopolo della formazione estesa alle 16 località è $148^{\circ} \mathrm{E}, 42 \circ \mathrm{N}$ $\left(\mathrm{dp}=11.3^{\circ}, \mathrm{dm}=22.4^{\circ}\right)$. A seguito dell'omissione di 3 località, per le quali $\alpha 95^{\circ} \geq 30^{\circ}$, la nuova posizione del paleopolo diventa $172^{\circ} \mathrm{E}, 26^{\circ} \mathrm{N}$.

Questa formazione geologica del Cambriano inferiore è caratterizzata da un'inversione di polarità. 


\section{GEOLOGY}

The Caldwell Group is composed of sedimentary and volcanic rocks. The bottom part of this group is mainly constituted of green, purplish to red, grey and black shales, slates, siltstones and schists overlain by thick-bedded, green, reddish and grey, arkosic quartzites and sandstones, with some intermingled grey, green, and red fissile arenaceous slates and shales. The majority of the beds are thin and some are quartzitic, sandy and silty. Immediately beneath the Caldwell lavas, there is an appreciable thickness of highly fissile pure grey slate which passes to a green and more frequently to a red colour near the top; it is apparently a variety of tuff.

The Caldwell volcanics composed of massive and pillowed lavas, breccias, agglomerates and tuffs, occupy the top part of the Caldwell Group. Only the lavas and in particular the pillowed lavas were sampled in this sequence. The Caldwell lavas are predominantly basaltic, with a little associated andesite.

These rock sequences were originally termed Caldwell Series (now Group) by McKay (1921) and Tolman (1936) in the Beauce region. Béland (1957), Benoît (1957, 1958a,b) and A. Rouleau (1975, M.Sc. thesis in preparation) studied the geology of the Caldwell Group in the St-Sylvestre area and north of it.

Knox $(1916,18)$, Harvie (1923), Cooke (1938, 50, 54, 55), Riordon (1953, 54, 57), Derosier (1971), Lamarche (1973), and St-Julien (1975) have undertaken petrologic and structural studies of the Caldwell Group in the Thetford Mines-Black Lake area and south of it.

The Sutton-Bennett schists located to the south west of the Thetford Mines-Black Lake area grade into the Caldwell Group as the metamorphism decreases gradually in a northeasterly direction. The Bennett chloritoschists are the metamorphosed and schistose equivalent of lavas and tuffs of the Caldwell Group (Cooke, 1938; St-Julien and Hubert, 1975). 


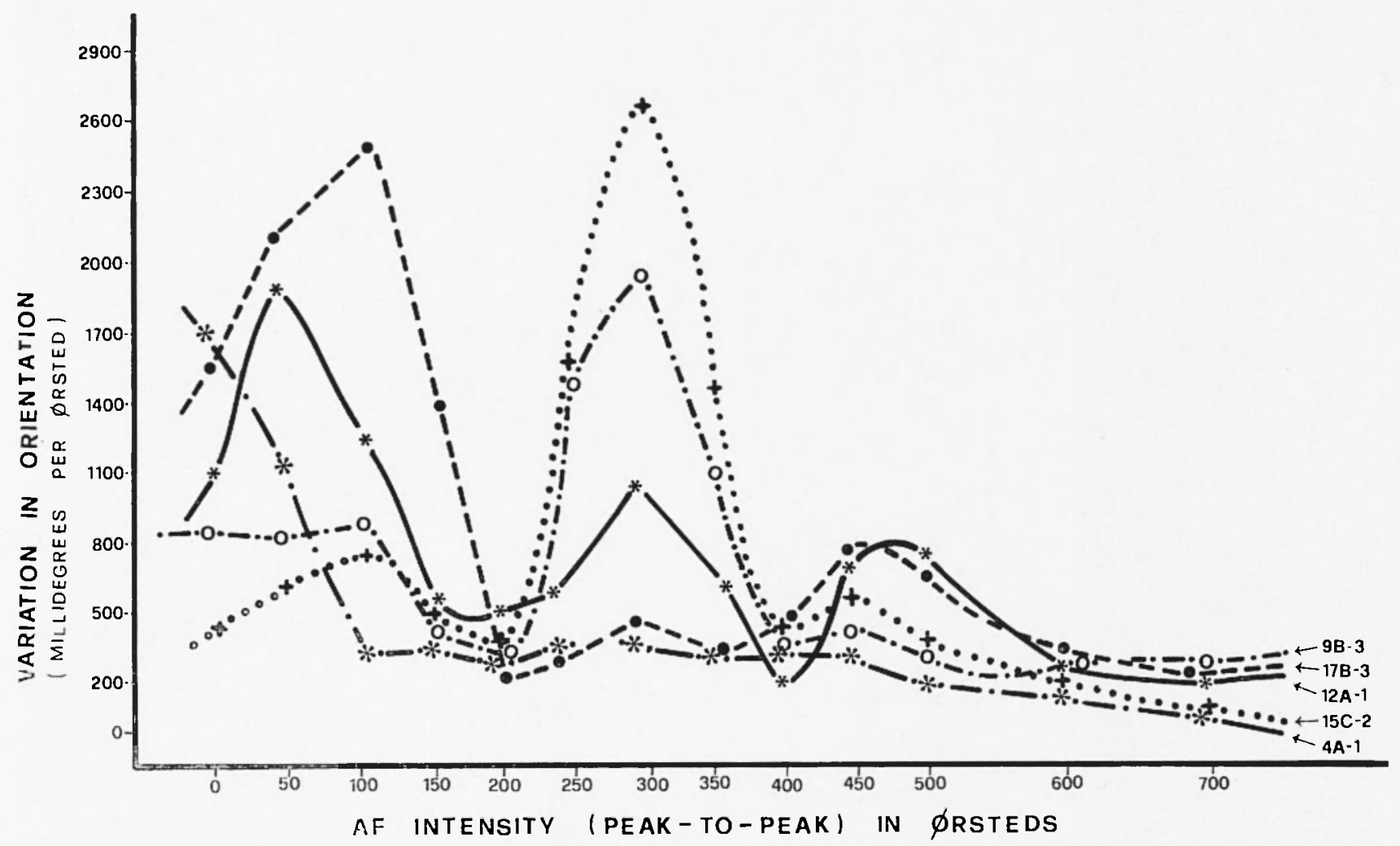

FIG. 1 - Graph of the stability index of 5 specimens of the Caldwell Group. 
AGE

The Caldwell Group is located stratigraphically below an ophiolitic sequence which gave a radiogenic (K/Ar) age of 550 m.y. Consequently, the Caldwell Group which is definitely overlying the Grenville basement (late Precambrian) has an age between that of Grenville basement and 550 m.y.

\section{SAMPLING PROCEDURE}

42 oriented samples (97 specimens) were collected at 17 different sites; the orientation was done with a Brunton or a solar compass. The number of samples per site varied between 2 and 4 and the number of specimens per sample bettween 2 and 5. The samples were drilled in the field with a portable diamond drill. In this survey, efforts were made to select sites where there was an excellent exposure and where the structural geology was rather simple and well understood. Great care was also taken to select relatively fresh material. The sample locations were chosen by reference to detailed geological maps published by Cooke (1938) at a scale of 1 mile to the inch.

\section{MEASUREMENTS}

The direction and intensity of remanent magnetization were measured with a Princeton Applied Research Model SM-1 spinner magnetometer (sensitivity: $10^{-7} \mathrm{cgs}$ emu). Alternating field demagnetization was carried out to remove unwanted secondary components using a demagnetizer built at the University of Laval (maximum peak field intensity of $1800 \varnothing$ rsteds) the performance of which was improved by adding 3 large concentric mu-metal cylinders around the solenoid. 
INITIAL N.R.M. INTENSITIES AND DIRECTIONS

The N.R.M. intensities range from $2.0 \times 10^{-6}$ to $3.5 \times 10^{-3}$ $\mathrm{emu} / \mathrm{cm}^{3}$. The high intensity values are found either in hematitic specimens or in samples having a relatively high magnetite content. Hematite and magnetite were identified with a reflecting light microscope. The mean N.R.M. direction of the Caldwell Group in-situ $\left(350^{\circ},-43,95=13.7^{\circ}, K=62.2\right)$ is quite different from the local Earth's field $\left(343^{\circ}, 70^{\circ}\right)$ indicating that an important fraction of the remanence is of ancient origin. After rotating the formation to the horizontal, the mean N.R.M. direction is $352^{\circ}, 09^{\circ},\left(\alpha 95=21.4^{\circ}, K=53.1\right)$. The increase in $\alpha 95$ and the decrease of $K$ suggest that at least a fraction of the N.R.M. component is post-folding.

\section{Af DEMAGNeTIZATION}

A minimum of 2 specimens (usually 3 or 4 ) from each site were demagnetized, i nsteps of 50 Ørsteds, from 50 to 500 $\varnothing$ rsteds and in steps of $100 \varnothing$ rsteds, from 500 to $800 \varnothing$ rsteds in the absence of an ambient field. A few treatments up to 1500 $\varnothing$ rsteds were done. Guided by the stepwise changes in orientation and intensity of the pilot specimens from a site, 2 stregths of AF demagnatization were selected using an "specimens from a site were AF demagnetized and their residual remanence measured. Pilot tests show that the AF strength at with the primary thermoremanent component is most thoroughly isolated is located in the $150-250 \varnothing$ rsteds range or the $500-700 \varnothing$ rsteds range (figure 1). Normalized demagnatization intensity curves for the same test specimens from different sites are shown in figure 2 .

The behaviour of the orientation and intensity of the residual remanence is quite complicated and difficult to interpret 


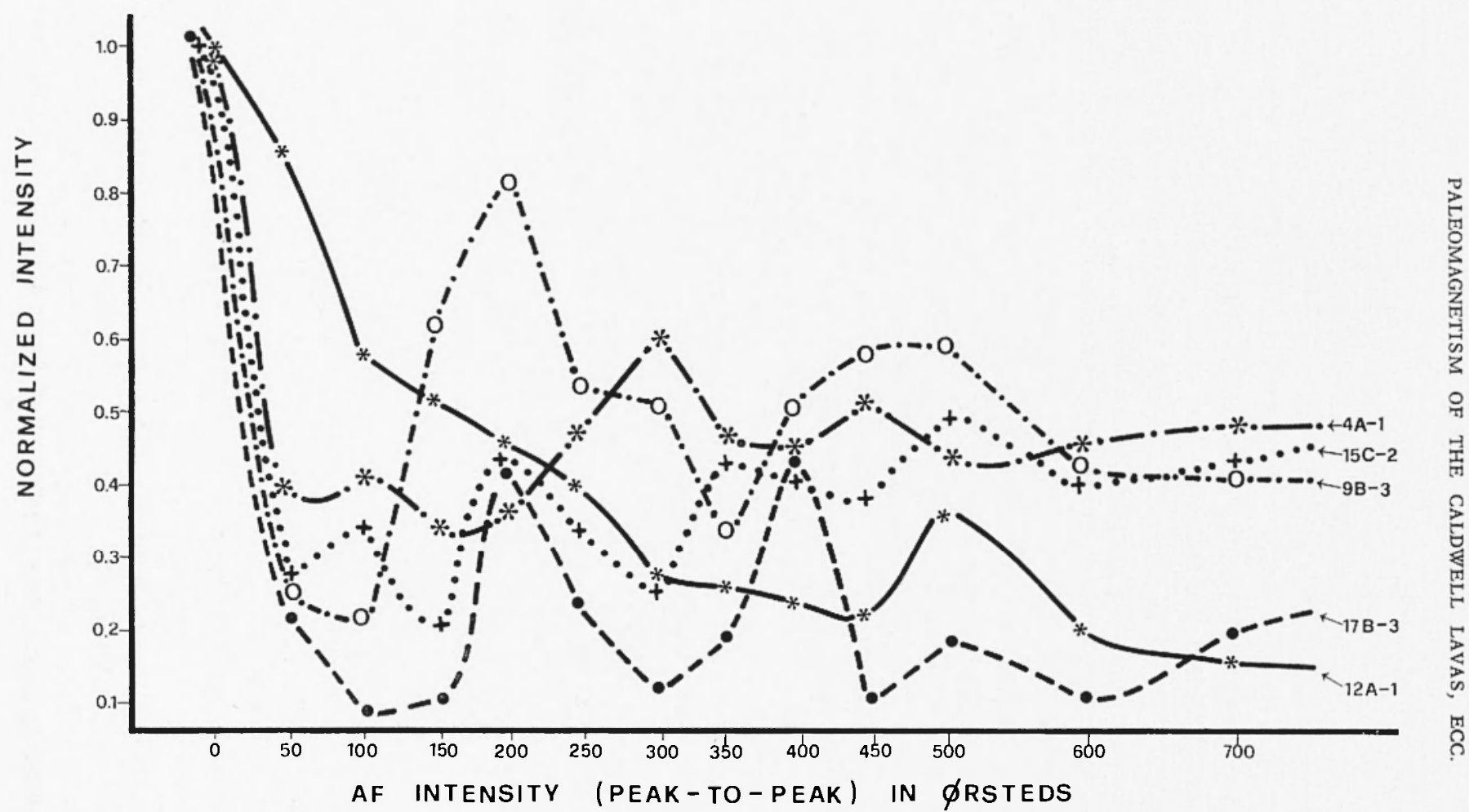

Fig. 2 - Normalized remanent intensity of 5 typical specimens of the Caldwell Group as a function of the demagnetizing field strength. 
(figures 1 and 2). A statistical study of the orientations of the residual remanent components was carried out for both $\mathrm{AF}$ strength ranges; only $60 \%$ of the pilot specimens used indicated a relatively stable N.R.M. component in the 150-250 Ørsteds range. This statistical study was done for the Caldwell Group in its actual structural setting and then folded back to its original position (table I). After demagnetization, the inclination of the site mean directions of the tilted formation displaced from the northern towards the southern hemisphere. About $55 \%$ of the pilot specimens depict an intensity increase of the residual component in the 200-500 $\varnothing$ rsteds range and this increase is frequently accompanied by a polarity inversion. The decrease in intensity of the residual component is quite rapid in the 50-250 Ørsteds range; the median destructive field occurs in the 30-225 Ørsteds range (mean $75 \varnothing$ rsteds) with one notable exception where it is larger than $700 \varnothing$ rsteds. The significance and stability of the remanent component in the Caldwell Group are demonstrated by the departure of the orientations of the AF cleaned residual component from the recent Earth's field direction and the evidence for reversal(s).

After AF demagnetization in the 500-700 $\varnothing$ rsted range and tilting of the formation, the paleopole position of the Caldwell Group is $328^{\circ} \mathrm{E}, 43^{\circ} \mathrm{S}$ (north pole), i.e., $148^{\circ} \mathrm{E}, 43^{\circ} \mathrm{N}\left(d_{m}=22.4^{\circ}\right.$, $d_{p}=11.3^{\circ}, K=23.6$, reverse polarity). After exclusion of the 3 sites for which $\alpha 95-30^{\circ}$, the orientation of the residual remanence is $142^{\circ},-30^{\circ}\left(\alpha 95-19.5^{\circ}\right)$ and the corresponding paleopole position is $352^{\circ}, 26^{\circ} \mathrm{S}(N)$, i.e. $172^{\circ} \mathrm{E}, 26^{\circ} \mathrm{N}(R)$. This last value is retained as the best estimate of the paleopole position for the Caldwell Group.

DISCUSSION OF THE RIESULTS

This paleomagnetic study is the first to be conducted in the Caldwell Group which is one of the oldest lithological unit of the Appalachians of southern Quebec. In spite of difficulties encountered in the interpretation of the AF demagnetized results, 
TABLE 1

Remanent Magnetization directions after AF demagnitization

\begin{tabular}{|c|c|c|c|c|c|c|c|c|c|c|c|c|c|c|c|c|c|c|}
\hline \multirow{2}{*}{$\begin{array}{l}\text { Site } \\
\text { No }^{0}\end{array}$} & \multirow{2}{*}{$\begin{array}{l}\text { Strike } \\
\left({ }^{\circ}\right)\end{array}$} & \multirow{2}{*}{$\underset{(0)}{\operatorname{Dip}}$} & \multirow{2}{*}{$\begin{array}{c}\text { Number of } \\
\text { samples }\end{array}$} & \multirow{2}{*}{$\begin{array}{c}\text { Number of } \\
\text { specimens }\end{array}$} & \multicolumn{3}{|c|}{ Formation in-situ } & \multirow{2}{*}{$\begin{array}{l}\text { Alt. field } \\
\text { ( } \varnothing \text { rsteds) }\end{array}$} & \multicolumn{3}{|c|}{ tilted } & \multicolumn{3}{|c|}{ Formation in-situ } & \multirow{2}{*}{$\begin{array}{l}\text { Alt. field } \\
\text { ( } \varnothing \text { rsteds) }\end{array}$} & \multicolumn{3}{|c|}{ tilted } \\
\hline & & & & & $\begin{array}{l}D_{1} \\
(0)\end{array}$ & $\begin{array}{l}\mathrm{I}_{1} \\
\left(^{\circ}\right)\end{array}$ & $\begin{array}{c}\alpha 95 \\
\left({ }^{\circ}\right)\end{array}$ & & $\begin{array}{l}D_{2} \\
\left({ }^{\circ}\right)\end{array}$ & $\begin{array}{l}\mathrm{I}, \\
\left(^{\circ}\right)\end{array}$ & $\begin{array}{c}\alpha 95 \\
\left({ }^{\circ}\right)\end{array}$ & $\begin{array}{l}D_{1} \\
(0)\end{array}$ & ${ }_{(0)}^{1}$ & $\begin{array}{l}\alpha 95 \\
\left({ }^{\circ}\right)\end{array}$ & & $\begin{array}{l}\mathrm{D}, \\
\left({ }^{\circ}\right)\end{array}$ & $\begin{array}{l}\mathrm{I}, \\
\left({ }^{\circ}\right)\end{array}$ & $\begin{array}{l}\alpha 95 \\
(0)\end{array}$ \\
\hline 1 & 257 & $75 \mathrm{~N}$ & 2 & 5 & 311 & -37 & 19.6 & $100-200$ & 007 & -18 & 42.0 & 094 & 08 & 35.1 & $600-700$ & 120 & 42 & 19.9 \\
\hline 2 & 224 & $85 \mathrm{~N}$ & 2 & 6 & 288 & -20 & 23.9 & $100-200$ & 225 & -51 & 30.5 & 194 & -45 & 49.3 & $600-700$ & 207 & -64 & 25.6 \\
\hline 3 & 230 & $74 \mathrm{~N}$ & 2 & 5 & - & - & - & - & - & - & - & 261 & -33 & 16.1 & 700 & 206 & -35 & 14.7 \\
\hline 4 & 246 & $84 \mathrm{~N}$ & 4 & 10 & - & - & - & - & - & - & - & 267 & 10 & 13.2 & $500-700$ & 236 & 19 & 17.3 \\
\hline 5 & 217 & $68 \mathrm{~N}$ & 2 & 5 & - & - & - & - & - & - & - & 019 & 16 & 24.8 & $500-700$ & 063 & 07 & 18.7 \\
\hline 6 & 246 & $72 S$ & 2 & 5 & - & - & - & - & - & - & - & 017 & 05 & 45.1 & $500-600$ & 041 & 39 & 56.3 \\
\hline 7 & 240 & $64 \mathrm{~N}$ & 2 & 7 & 271 & 34 & 19.3 & 200 & 177 & -19 & 17.9 & 254 & 60 & 33.9 & $600-700$ & 178 & -31 & 28.6 \\
\hline 8 & 242 & $85 \mathrm{~N}$ & 2 & 4 & - & - & - & - & - & - & - & 250 & -15 & 36.1 & $600-700$ & 257 & 06 & 36.8 \\
\hline 9 & 287 & $74 \mathrm{~N}$ & 2 & 5 & 357 & -14 & 32.0 & $150-200$ & 117 & 77 & 32.0 & 206 & -39 & 24.6 & $500-700$ & 004 & -27 & 24.5 \\
\hline 10 & 233 & $75 \mathrm{~N}$ & 2 & 5 & 022 & 25 & 31.4 & $150-200$ & 120 & 15 & 31.5 & 347 & 75 & 6.6 & 700 & 139 & -03 & 6.5 \\
\hline 11 & 226 & $45 S$ & 3 & 7 & - & - & - & - & - & - & - & 334 & 41 & 12.1 & $500-700$ & 039 & 76 & 12.4 \\
\hline 12 & 225 & $58 \mathrm{~S}$ & 3 & 6 & 327 & 61 & 28.7 & $150-250$ & 184 & 32 & 14.4 & 194 & 07 & 36.4 & $600-700$ & 214 & -19 & 402 \\
\hline 13 & 239 & $62 S$ & 1 & 3 & - & - & - & - & - & - & - & - & - & - & 600 & - & - & - \\
\hline 14 & 249 & $83 S$ & 3 & 7 & 226 & -55 & 47.6 & $100-150$ & 131 & 14 & 47.5 & 039 & -12 & 11.8 & $600-700$ & 099 & -24 & 9.8 \\
\hline 15 & 183 & $86 \mathrm{~W}$ & 3 & 7 & 145 & 11 & 32.3 & $150-200$ & 166 & -36 & 32.1 & 155 & -11 & 23.2 & $500-700$ & 204 & -24 & 23.3 \\
\hline 16 & 238 & $85 \mathrm{~N}$ & 3 & 8 & 272 & -23 & 34.3 & 150 & 258 & 33 & 20.6 & 323 & -56 & 19.8 & $500-700$ & 324 & 37 & 19.7 \\
\hline 17 & 229 & $63 \mathrm{~S}$ & 3 & 9 & 326 & -16 & 33.0 & $200-250$ & 345 & -17 & 30.2 & 026 & -23 & 28.3 & $600-700$ & 020 & 07 & 28.5 \\
\hline- & & & - & - & - & - & - & - & - & - & - & - & - & - & - & - & - & - \\
\hline 17 & & & 41 & 104 & 332 & 01 & 26.2 & 200 & 178 & 03 & 25.8 & 320 & -13 & 20.2 & 600 & 156 & -26 & 22.2 \\
\hline
\end{tabular}

paleopole position: $\quad 147^{\circ} \mathrm{E} \omega 28^{\circ} \mathrm{N} \quad 300^{\circ} \mathrm{E} \omega 39^{\circ} \mathrm{S} \quad\left(d_{p}=13^{\circ}, d_{m}=27^{\circ}\right) \quad 154^{\circ} \mathrm{E} \omega 26^{\circ} \mathrm{N} \quad 148^{\circ} \mathrm{E} \omega 43^{\circ} \mathrm{N}\left(d_{p}=11.3^{\circ}, d_{m}=22.4^{\circ}\right) 328^{\circ} \mathrm{E} \omega 43^{\circ} \mathrm{S}$ 


\section{LAMBERT EQUAL AREA PLOT}
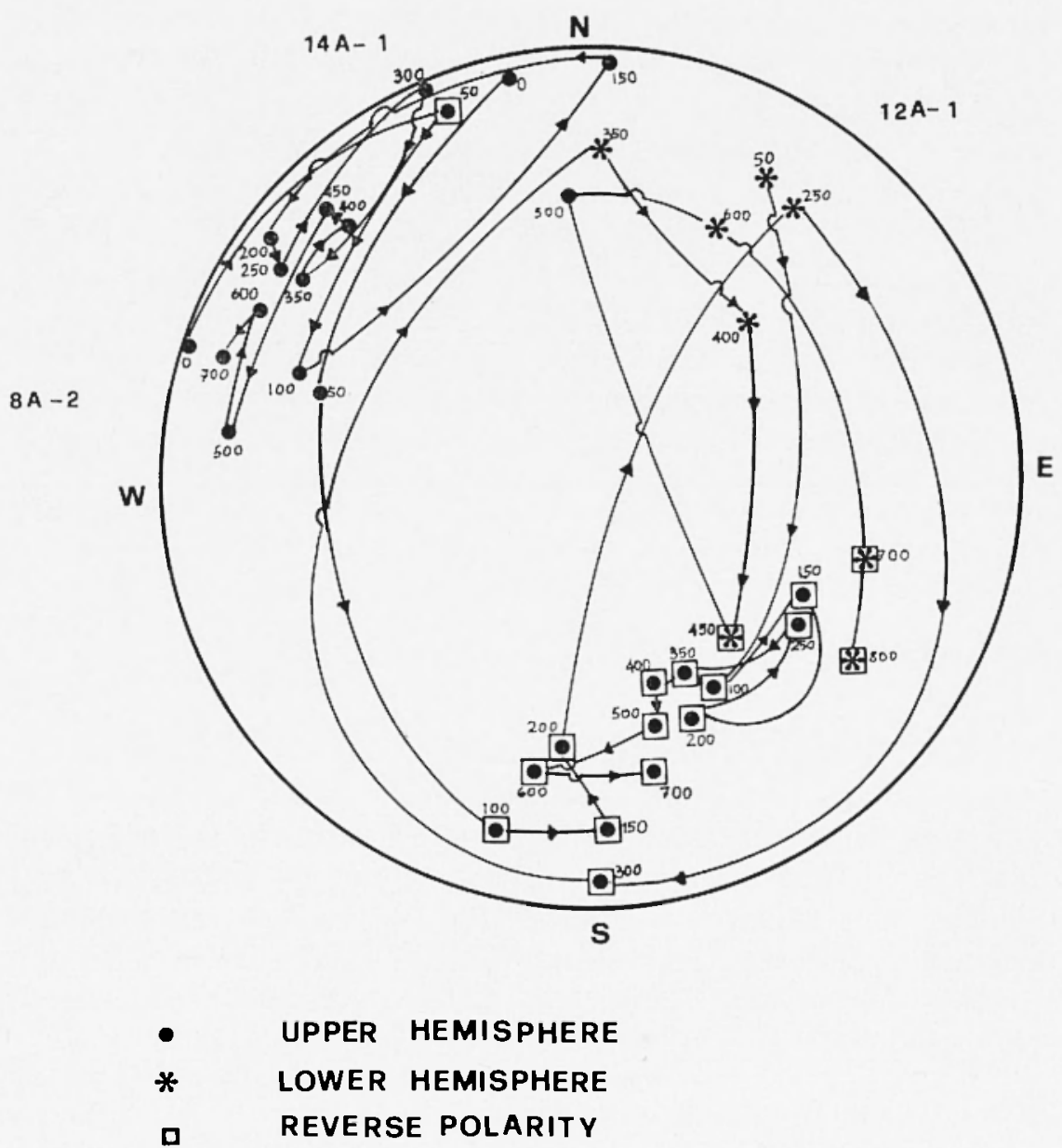

Fig. 3 - Variation of the magnetization directions of 3 pilot specimens of the Caldwell Group as a function of the AF demagnetizing strength. 
it is more probable that the original thermoremanent component was successfully isolated and a fair amount of confidence may be attached to the paleopole position $\left(172^{\circ} \mathrm{E}, 26^{\circ} \mathrm{N}\right)$ of the Caldwell Group which is of Early Cambrian age. Three reliable pole available from Cambrian rocks of North America are listed in McElhinny (1973). Their mean position is $141^{\circ} \mathrm{E}, 08^{\circ} \mathrm{N}$ $\left(\alpha 95-22^{\circ}, K=31\right)$ and in all cases, the polarities are mixed or reversed. The paleopole position obtained in this study is thus located further to the east. The paleopole position obtained after AF treatment in the 150-250 Ørsteds range and without tilting of the formation could logically coincide with the Taconian orogeny (Late Ordovician-Early Silurian time). The pole position obtained is $147^{\circ} \mathrm{E}, 28^{\circ} \mathrm{N}\left(d_{m}=25.2^{\circ}, d_{p}=12.9^{\circ}, K=34.7\right.$, reverse polarity); it falls midway between the Ordovician and Silurian pole position (McElhinny, 1973).

On this basis, it appears that both the original thermoremanent and the superimposed orogenic events were imprinted on Caldwell rock formations and that these magnetic events can be isolated by progressive AF demagnetization.

\section{ACKNOWLEDGMENTS}

The writer thanks Mr. D. Lafond who made many of the measurements and Mrss. J.L. Roy and P. Lapointe of the Division of Geomagnetism, Earth Physics Branch, Ottawa, who contributed to this study throughout numerous discussions and advice. This research was supported by the National Research Council of Canada (Grant No: A7070-110 [1974-75]) and by the Energy, Mines and Resources, Canada, Research Agreement No.: 1135-D13 - 3 - 55/75-76. 


\section{REFERENCES}

BÉLANd J., 1957 - St-Magloire and Rosaire - St-Pamphile Areas. Dept. of Mines, Québec. Geol. Rept. No. 76.

Benoît F.W., 1957 - St-Sylvestre Area. Dept. of Mines, Québec, Prelim. Rept. No.: 347.

Benoît F.W., 1958a - St-Sylvestre - St-Joseph (West Half) Areas. Dept. of Mines. Québec, Prelim. Rept. No.: 359.

Benoît F.W., 1958b - Geology of the St-Sylvestre and St-Joseph West Half Area. Thèse de D.Sc., Université Laval, Québec, 116 pp.

СоОкE M.H.C., 1938 - Régions de Thetford, de Disraeli et de la moité orientale de Warwick (Québec). "Comm. Géol.", Canada, Mémoire 211, $176 \mathrm{pp}$.

Сооке, M.H.C., 1950 - Geology of a Southwestern Part of the Eastern Townships, Québec. "Geol. Surv. Can», Memoir 257.

COOKE M.H.C., 1954-55 - Geology of Arthabasca Map - Area and the Bast Half of Lyster Map-Area. Dept. of Mines, Quebec, Open file Rept.

Derosier C., 1-971 - Etude géologique des brèches de la région de Thetford Mines, Province de Québec, (Canada). Thèse de doctorat du 3 ¿ेme cycle, Univ. de Paris VI, Paris, $107 \mathrm{pp}$.

Harvie R., 1923 - Thetford Map - Area. "Geol. Surv. Can ", Unpublished Report.

Knox J.K., 1916 - Partie sud-ouest du district minier de Thetford Black Lake. Comm. géol. Canada, Rap. somm. 1916, p. 229-245.

KNox J.K., 1918 - Geology of the Serpentine Belt, Coleraine Sheet, Thetford - Black Lake Mining District, Quebec. Thèse Ph. D., Département de Géologie, Université de Chicago, édition particulière, distribuée par l'University of Chicago Libraries.

Lamarche R.Y., 1973 - Géologie du complexe ophiolitique d'Asbestos, Cantons de l'Est, Québec. "Dept. Nat. Res. Geol. ", Rept. 28558, 9 pp.

McElhinny M.W., 1973 - Paleomagnetism and plate tectonics. Cambridge University Press, London, U.K., 358 pp.

McKay B.R., 1921 - Beauceville Map-Area. Beauceville Map-Aria, Québec. "Geol. Surv. Can. Memoir », 127.

RIORDON P.H., 1953 - Geology of Thetford Mines - Black Lake area, with particular reference to the Asbestos deposits. Ph. D. Thesis, McGill Univ., Montréal, 236 pp. 
RioRDon P.H., 1954 - Thetford Mines - Black Lake Area, Frontenas, Megantic and Wolfe Counties. Dept. of Mines Québec, Prelim. Rept. No.: 295, 23 pp.

RIORDON P.H., 1957 - The Asbestos belt of soutern Québec. In: The Geology of Canadian industrial mineral deposits, Commonwealth Min. Congr., Canada, p. 3-8.

ST-Julien P., 1975 - Géologie des Régions de St-Victor et de Thetford Mines (moitié est). Min. Rich. Nat., Québec. Manuscript.

St-Julien P., Hubert C., 1975 - Evaluation of the Taconian orogen in the Quebec Appalachians. "Amer. Jour. of Science ", 275-A, p. 337-362.

Tol.man C., 1936 - Lake Etchemin Map-Area, Québec. Geol. Surv. Canada, Memoir 199. 